\title{
The Transfer of Science and Technology between Asia and Europe
}

\author{
OM PRAKASH \\ (Delhi School of Economics)
}

I consider it a great honour to be asked to participate in this colloquium, which has been organized to coincide with the inauguration of the Institute for the History of European Expansion at this premier university. Ever since the establishment of the earlier incarnation of this Institute, namely the Centre for the History of European Expansion, in the 1970s, there has been an ongoing cooperation between the Centre and my own university, the University of Delhi. The cooperation which began in 1976-77 - when I spent an extremely fruitful year here mainly working at the Algemeen Rijksarchief in The Hague, but also interacting with colleagues at the Centre and at the Kern Institute - took an institutional form in 1983 when the idea of the Cambridge-Delhi-Leiden-Yogyakarta Project on the Comparative History of India and Indonesia first began taking shape. The idea had actually germinated in the course of discussions between the chairman of this meeting, Henk Wesseling, and my colleague at the Delhi School of Economics, Dharma Kumar, both of whom had spent the year 1980-81 at the Institute of Advanced Study at Princeton. The idea of cooperation was warmly supported by each of the four universities and it was decided to hold a series of four conferences. The Centre for the History of European Expansion assumed the role of coordinator for the project and the four conferences were held respectively at the universities of Delhi, Leiden, Yogyakarta and Cambridge between 1985 and 1987. The proceedings of the four conferences have since been published both in special numbers of Itinerario as well as in volumes published by E.J. Brill. Quite apart from the academic.achievements of the project, a major gain was made in terms of the establishment of direct personal and academic contacts between scholars in the four universities, and particularly between those at Delhi and Yogyakarta.

Last year, the Centre again took the initiative in formulating yet another research project which would involve not only the four universities of Cambridge, Delhi, Leiden, and Yogyakarta but also universities in Japan and China. It is the theme of this new project - the transfer of science and technology between Asia and Europe - that I have chosen as the topic of 
my brief talk to this distinguished audience this afternoon. Let me begin by saying that I have no particular or specialized knowledge of the history of either science or technology or of that of their transfer across continents. My interest in the subject derives basically from my concern with the history of the commercial, and more generally the economic, relationship between Asia and Europe - a relationship that started on a systematic basis five centuries ago to the decade. The evolving pattern and the phases in the transfer of science and technology between the two continents both conditioned, and in turn was conditioned by, the changing nature of the economic relationship between Europe and Asia. In the case of India and many other Asian societies, the period until about the middle of the eighteenth century was one where the relationship with Europe was confined principally, though not exclusively, to trade, and the Portuguese Estado and later the Dutch, the English, and the French East India Companies were the principal connecting links between the two continents. As a result, these enterprises also became the principal vehicles for whatever transfer of science and technology took place between the two continents during this period.

From the late eighteenth century on, however, as the relationship between the principal European powers and the Asian societies increasingly became colonial in character, the avenues of the transfer of science and technology between the two continents increased considerably. The information based on the transfer of science and technology, as well as the nature of this transfer, underwent a significant change between these two broad periods. For the pre-colonial phase, the information base consists of the European travellers' accounts as well as of the material available in the documentation of the European trading companies. The information in the travel literature is concerned overwhelmingly with the commentators' perceptions regarding the differences between the levels of scientific and technological achievements in various fields as between the various societies in the two continents rather than on the actual process of the transfer. As far as the European company documentation is concerned, the available information relates both to comments on the differences in the levels of achievements as well as on the actual process of transfer to the limited extent to which the companies themselves were instrumental in effecting such a transfer. One could perhaps legitimately argue that during this phase, the transfer was overwhelmingly one way from Europe to Asia, was rather limited in range and scope, and was confined largely to technology rather than science. The companies' involvement in the whole thing took the shape primarily of actual problem-solving in the matter of the procurement of goods in Asia for the European and other markets and their transportation to the relevant consuming markets.

From the late eighteenth century on, however, the relationship between the two continents came to be based much more broadly, rather than remaining simply a commercial relationship. While actual problem-solving 
continued to be important, and technology transfer evidently continued, the concerns became much wider in scope. The transfer of scientific knowledge in such critical areas as agriculture and medicine now dominated the scene. The period also witnessed the start of scientific societies and other institutions directed at the growth and the dissemination of scientific research.

As far as the pre-colonial period is concerned, the information base, as I mentioned earlier, consists of the travel literature as well as the European company documentation. As far as scientific knowledge was concerned, the general European view regarding India, as reflected in the travel literature, was that Indians had in the past excelled in the sciences, particularly astronomy, medicine and mathematics. But the early promise of Indian scientific discoveries had not been fulfilled and scientific thinking had stagnated and became mired in superstition and mythology. By the same token, over a period of time, Europe had acquired a substantive differential advantage over Asia in this respect. In the matter of technological development, while it was clearly recognized that in particular industries such as cotton textiles and porcelain manufacturing, Asian producers had a distinct edge over their European counterparts, the range and the sophistication of Asian tools and implements was generally recognized to be considerably inferior to that of those used in Europe.

As far as the European company documentation is concerned, if one examined the available evidence in selected areas such as minting, textile and shipbuilding technology, a very interesting picture emerges. To begin with minting technology, the Indian records of the Dutch East India Company for the late seventeenth and the early eighteenth centuries contain not only a detailed description of the various processes involved in minting gold, silver and copper bullion into coins, and the regional differences between northern and southern India in this respect, but also a detailed itemized account of the elements in the structure of the minting costs at both the centralized imperial North Indian mints as well as the decentralized South Indian mints. I do not know of any other source which contains this kind of information at this level of detail.

From my present point of view, however, perhaps an even more interesting part of detailed information available is the Dutch Company factors' perception of the gap in the level of sophistication of the technology used in the European and the Indian mints respectively. As far as the Indian mints were concerned, as one would expect, the technology used was basically pre-industrial non-mechanized hand-technology. There is also no evidence to suggest the use of animal power in conducting the stamping or any other operation while the use of such power had been known in European mint technology since at least the seventeenth century. Basically, the technique used in the Indian mints was that of striking the coin by placing a metal blank between engraved dyes which were then pressed by hammer blows manually. The Dutch perception of the Indian minting 
technology was that it was both poor and wasteful. In 1720, for example, Anthony van der Meule, the Dutch factor responsible for organizing the minting of the Company's bullion at the Murshidabad mint, noted that he 'could not be surprised enough about the slovenly, unprecedented and detrimental methods used at the mint for refining and smelting the silver species'. Van der Meule also talked of the refining and smelting procedures followed in the Murshidabad mint and their counterparts in a European mint. According to him, the Murshidabad procedures were incapable of achieving perfect results in either field. He then made the exceedingly significant statement that for a refining job for which five to six workers would suffice in a European mint, the Murshidabad mint employed one hundred and twenty or more workers including refiners, blowers and beaters.

This kind of information throws up exceedingly important issues of both analysis and interpretation. Even allowing for a certain margin of error in Van der Meule's estimates of the relative size of the workforce needed in an Indian as against a European mint for a given amount of work, there can be no doubt that the Indian mint technology was comparatively less sophisticated and extremely labour-intensive. But can this also necessarily be termed as being an inferior and inappropriate technology? Some important considerations need to be taken into account before this question can be answered. One is the important differences in the structure of factor endowments between the European economies and India, with the latter being relatively much more generously endowed with supplies of cheap and skilled labour. This by itself would impart a measure of economic legitimacy to the use of labour-intensive technology. In such a technology, the workmanship of the artisan became a critical input in determining the quality and even the quantity of the output. On the question of the workmanship of the Indian artisans, the perception of the Indian commentators was quite different from that of the Europeans. Thus, talking of the cutters of metal ingots, Abul Fazl, the celebrated author of the Ain-i-Akbari wrote: 'In Iran and Turan they cannot cut these pieces without a proper anvil, but Hindustani workmen cut them without such an instrument, so exactly, that there is not the difference of a single hair, which is remarkable enough." The quality of the workmanship even affected the quantity of the output produced. Thus writing about the Rajmahal mint in 1676, the English factor, Richard Edwards observed that while a good artisan could stamp 1,000 coins a day, the output of a poor artisan would not exceed 700 to 800 pieces, and even of those, as many as 25 per cent would be poorly stamped.

The superb quality of the Indian artisanal workmanship showed through more than anywhere else in the manufacturing of high quality cotton, silk, and cotton and silk mixed textiles. These textiles, without question, were among the best produced anywhere in the world. It was not without reason that the best quality Dacca muslins carried names such as 'evening dew', 
'running water' and 'webs of woven wind'. According to Jean-Baptiste Tavernier, these muslins are made 'so fine, you can hardly feel them in your hand, and the thread when spun, is scarce discernible' ${ }^{2}$. Within the overall context of labour-intensive technology, it was essentially the availability of this quality of workmanship at a relatively low wage that put the Indian textiles in an unchallengeable position in the world market. It was only the Industrial Revolution in Britain in the latter half of the eighteenth century that robbed the Indian textile industry of its distinct cost advantage. Until that time, therefore, there really was no economic rationale for the introduction of significant labour-saving technological change in the Indian textile industry. But that is not to say that the textile sector was in any sense resistant to innovations of various kinds. Thus the sizes of the textiles as well as their texture, pattern, designs, and colour combinations were constantly modified to meet the changing configuration and the pattern of demand from the national and the international markets. The change in size often necessitated the resetting of the loom and the use of new matrices. To facilitate changes in design and colour combinations etc., the single most important buying group for the international market, namely the European trading companies, often brought in expert weavers and dyers from Europe to prepare new samples. The Dutch even started a unit within the precincts of their factory at Hugly, where experiments in new designs, patterns, and colour schemes were carried out.

A good example of an Indian industry where technological change was in fact incorporated on a fair scale in persuance of both economic as well as military considerations was the shipbuilding industry. While it is true that in specific areas of shipbuilding technology, differences between European and Indian practices persisted because no particular economic or other advantage was seen in adaptation, there were other areas where a great deal of innovation and adaptation took place. An example of the former was the continuing use of rabetting for joining the wooden planks in the Indian ships, while the traditional method used for the purpose in European shipping was that of caulking where the joint or seams were tightened by forcing oakom between parts that were not tightly fitted. On the other hand, the most important example of innovation and adaptation was the growing use of iron nails in Indian shipping. Thus at the important Coromandel shipbuilding centre at Narsapur Peta, where both teak and iron were available in plentiful supply, the construction of large vessels of 600 tons plus incorporating a considerable amount of European technological influence is recorded. It would seem that the shipbuilding tradition at Narsapur Peta derived in its early years (i.e. A.D. 1580-1620) from the dhow of the western Indian Ocean while at the same time displaying the influence of the private Portuguese presence in northern Coromandel in its liberal use of iron. In the period between 1620 and 1670, the ships seem increasingly to have exhibited 'European' traits - multiple decks, heavier armament, and changes in the rigging as well. From about the mid-seven- 
teenth century on, the Dutch and the English East India Companies as well as private English traders became important buyers of ships constructed at Narsapur Peta and other Indian shipbuilding centres such as Hugli in Bengal. Many of these ships were built on the basis of European designs and under European supervision. The Dutch Company and the English private traders used these ships in intra-Asian trade and generally found their performance extremely satisfactory. Information available in the records of the Dutch East India Company describes in detail the various processes involved in the construction of a ship together with detailed itemized estimates of the costs.

The middle of the eighteenth century witnessed the beginnings of two major developments - the establishment of a colonial relationship between Britain and India, and the Industrial Revolution in Britain and other western European societies. In their economic dimension, these developments spelt the end of the strong competitive position of Indian industry - particularly the textile sector - in the world market. The ability of Manchester and Lancashire to produce cheap standardized cotton textiles led to the Indian textiles being competed out of the world market, and in the nineteenth century India was reduced to the position of a significant net importer of machine-made textiles. An important question that arises at this state is why no labour-saving technological change took place in the Indian cotton textile industry at this point when there was complete economic justification and rationale for it. Traditional explanations of this phenomenon have run on the one hand in terms of the impact of colonial policy, and on the other in terms of the absence of a scientific temper and the presence of certain inherent economic and sociological characteristics in the Indian economy and society. In the present state of research on the subject, no definitive position is possible on this rather complex question. ${ }^{3}$

As far as the growth of science in British India is concerned, one can easily identify two principal objectives at work - how to make use of tropical resources and how to deal with the tropical health problems. Tropical agriculture and tropical medicine thus emerged as the two main planks of colonial Indian science policy. Initially, the research and development sponsored by the East India Company was agricultural in nature with purely commercial objectives. As early as 1788, the Manchester Cotton Textile Manufacturers' Association appealed to the Company to improve Indian cotton so that this cotton could meet the requirements of industrial processing. Since the Industrial Revolution in the British cotton textile industry coincided roughly with the American Revolution (which endangered the supply of American cotton) and the acquisition of India's government by the East India Company, it was understandable that the textile manufacturers would turn to the Company for a reliable source of raw materials. The Company responded favourable to the Association's request, and through farms and experimental gardens, sought to develop or introduce suitable varieties. Cotton improvement thus came to be among the India govern- 
ment's responsibilities as did the introduction of tea cultivation, spice cultivation, and the improvement of other items which included coffee, sugar, linseed, jute, silk and forest products. In the matter of the development of cotton, pecuniary advances were made to individuals; seeds were procured from Egypt, Brazil and North America; saw gins were brought to India; and large prizes were offered for best samples of cotton. Also American planters were brought to nurse experimental cotton farms.

At a more general level, the promotion of science and the transfer of scientific knowledge from Europe to India was to be achieved through the establishment of scientific societies. The period between 1784 and 1918 was the era of the Great Surveys and the formation of the Asiatic Society and its off-shoots. This period witnessed the institutionalisation of science through the development of field organisations for carrying out biological and geological surveys under the auspices of the Asiatic Society of Bengal. The years between 1918 and about 1924 saw the professionalisation of science through the establishment of universities in the Presidency towns and the setting up of the Industrial Commission which, in its report, outlined the requirements for the making of an industrial society.

It is during the period 1924 to the mid-1940s that the Science and Culture group of scientists led by Meghnad Saha began to advocate industrial research. Influenced by the Soviet model, they saw the overwhelming need for planning for science, but they too were not able to bridge the gap between pure science and industry. This link was to be provided only with the setting up of India's first national laboratory - the National Physical Laboratory - as the 'halfway house' between science and its industrial application in 1950.

Summing up then the growth of scientific knowledge in British India, one could legitimately argue that the British did develop and employed skillfully what Morris Berman calls 'the ideology of science'. The British certainly subscribed to a particular ideology of science. Theirs was a concept of science closely related to the needs of the empire. ${ }^{4}$

\section{Notes}

1 Ab-ü'l Fazl 'Allämī, The Ä̈n-i Akbari. Transl. H. Blochmann and H.S. Jarrett; 2nd rev. ed. by D.C. Phillott and Jadunath Sarkar (3 vols.; 1927-49; repr. New Delhi 1977-78).

2 Jean-Baptiste Tavernier, Travels in India. Transl. V. Ball; 2nd ed. by W. Crooke (2 vols.: London 1925).

3 T. Raychaudhuri and Irlan Habib (vol. 1), Dharma Kumar and M. Desai (vol. II), Cambridge Economic History of India (2 vols.; Cambridge 1982-83).

4 R. Dionne and R. Macleod, 'Science and Policy in British India, 1858-1914; Perspectives on a Persisting Belief in: M. Gaborieau and A. Thorner ed., Asie du Sud: traditions at changements. Sères 8-3 Juillet 1978 (Paris 1979) 55-68. 


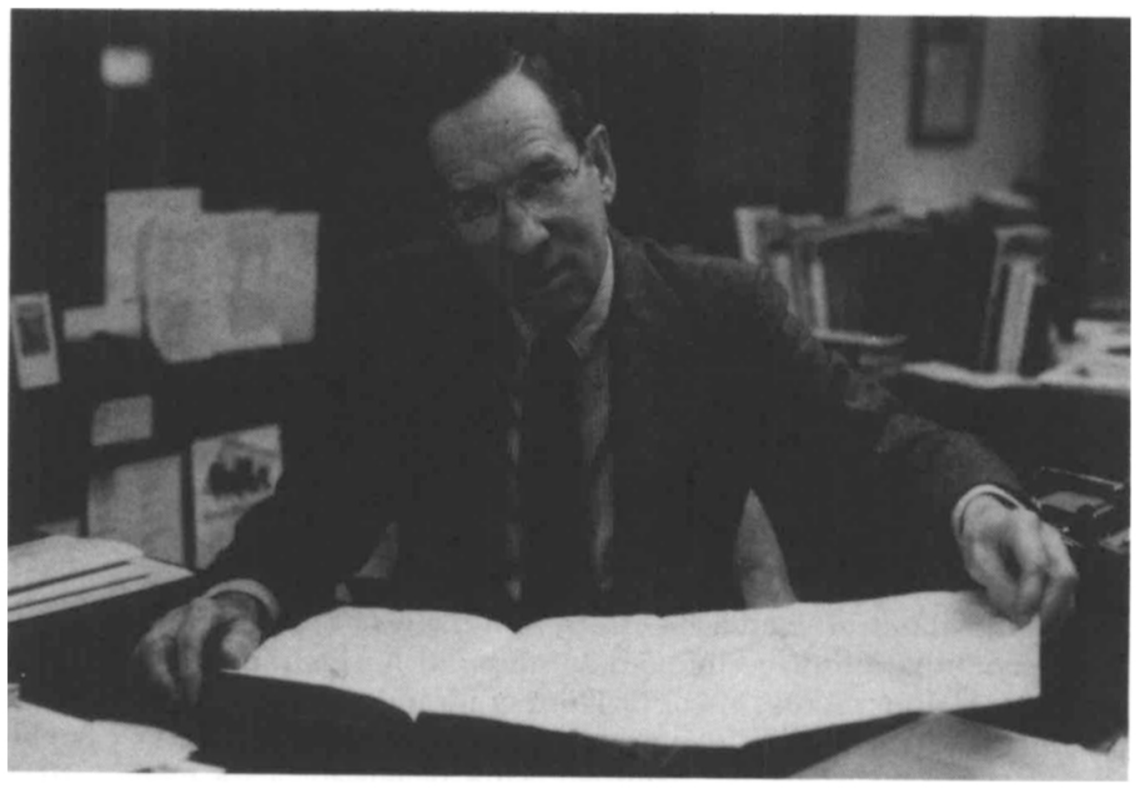

